\title{
Effects of Low-Impact Development on Urban Rainfall Runoff under Different Rainfall Characteristics
}

\author{
Zheng Peng, Ke Jinyan, Pan Wenbin*, Zhan Xin, Cai Yuanbin \\ College of Environment and Resources, Fuzhou University, Fuzhou, Fujian 350116, China
}

Received: 13 December 2017

Accepted: 15 February 2018

\begin{abstract}
Low-impact development (LID) is generally regarded as an effective solution for urban stormwater management. However, the effects of LID on storm flooding on an urban drainage systems scale have not been fully understood under different rainfall characteristics. In this paper, using a high-density residential catchment in China as a case study, the PCSWMM model is applied to simulate the control effects of seven LID land layout scenarios on water quantity and quality of rainfall runoff under different rainfall return periods, durations, and locations of peak rainfall intensity. The simulations indicated the following results: (1) All seven LID scenarios are more effective in flood control during smaller rainfall return periods and longer rainfall duration storms, and the influence of locations of peak rainfall intensity on the rainfall runoff is not obvious. (2) Permeable pavement is the best choice in single LID measures, and the combination of permeable pavement, vegetative swale, and a green roof is the best choice among combined LID layouts. This paper gives insight into the performance of LID designs under different rainfall characteristics, which is essential for effective sponge city construction.
\end{abstract}

Keywords: low impact development, PCSWMM model, urban rainfall runoff, rainfall characteristic, design storm

\section{Introduction}

With the accelerating development of urbanization, the impervious surface coverage increases accordingly, which alters the original natural drainage system. On the one hand, it causes a decrease in runoff infiltration, increases surface runoff and flood peak discharge, and decreases the concentration time and load aggravation in municipal sewer systems; on the other hand, urban

\footnotetext{
*e-mail: Wenbinpan@fzu.edu.cn
}

climate characteristics are affected and urban rainfall characteristics are changed, forming urban "heat island," "rain island," and "dust hood" effects [1-5]. In addition, the pollutants in the first flush enter into the receiving water directly, greatly threatening water quality [6-9]. Therefore, China has proposed the sponge city concept, which is a city that would have good "flexibility" in terms of adapting to environmental change, responding to natural disasters, and so forth - similar to a sponge. The city could assist in water absorption, storage, seepage, and purification when it rains and could "release" and use the stored water when necessary [10-13]. 
The establishment of a low-impact development (LID) runoff system is key to the construction of a sponge city, with emphasis on maintaining and protecting natural field hydrological functions through small control facilities with dispersed sources [10, 14-16]. Germany was the first country to adopt governmental control systems of urban runoff, and runoff management laws and regulations, technology guidance, and economic incentive policies on LID were also established. The runoff management concepts and technology of the United States have generally changed from initial discharge, water quantity control, and water quality control to a LID source control, multi-objective control, and management system with combined pollution prevention and total quantity reduction were generally built [10]. Shenzhen, China, took the lead in introducing the LID concept in 2004. In the past decade, through the building of a LID demonstration area, the promulgation of relevant standards and policies and regulations as well as enhanced basic research and international exchanges in LID, the application of LID in Shenzhen City has achieved initial success [10, 17].

The abilities to reduce runoff and improve water quality through LID measures have been supported by many scholars from different countries. For example, Dietz and Clausen [18] performed a simulation study on the rainstorm runoff and pollutant concentration under traditional development and LID development modes. This research found that in comparison with the traditional development mode, exercising LID measures largely reduced the runoff volume and pollutant load capacity. Alfredo et al. [19] found that a green roof can put off and extend the discharge of roof surface runoff and reduce the runoff peak value in comparison with a traditional roof. Holman Dodds et al. [20] found that the greatest reduction in runoff quantity can be realized by adopting LID technology when the rainfall return period is relatively short or soil permeability is relatively high. Hood et al. [21] compared the rainfall floods of the low-impact residential development area of Watford, Connecticut, and a traditional residential development area. The LID measures reduced the runoff volume, runoff coefficient, and runoff peak value, and it led to the best reduction effect on runoff when the rainfall intensity was relatively small. Ahiablame et al. [22] used a L-THIALID model to simulate the control effect of different LID measures in two highly urbanized watersheds, and it was found that different LID setting scenes could reduce the runoff quantity and pollution load by $2-12 \%$. Lee et al. [23] found that if LID measures were adopted for a large basin, the reduction in the rainstorm runoff peak for a 50 -year return period and a 100 -year return period could reach $7-15 \%$.

Although the present control effect of LID measures on runoff has been investigated and evaluated for all neighborhoods and laboratories, there are still very few studies that have focused on the control effects of the signal and combined LID measures on a small basin under different rainfall characteristics. Thus, the primary objective of this research is to simulate the control effects on the surface runoff water quantity and quality of a built-up urban area by comparing 7 types of LID land layout scenarios (single and combined measures) with current land layout scenarios under different rainfall characteristics (rainfall return period, rainfall duration, and locations of peak rainfall intensity). This research provides insight into the performance of LID designs under different rainfall characteristics, which is essential for effective sponge city construction.

\section{Material and Methods}

\section{Study Area}

The study catchment is located in a high-density residential area in the Jiefangxi drainage basin, Jin'an District, Fuzhou City, southeast China, with an area of 75.84 ha (Fig. 1). The impermeable area accounts for $71.37 \%$ of the total area and is primarily composed of roofs, squares, parking lots, roads, and other impervious surfaces; the permeable area accounts for $28.63 \%$ of the total area and is primarily composed of community virescence. The average ground level of the study area is $12.58 \mathrm{~m}$, the average slope is $3.72 \%$, the agrotype is primarily loam, and the pavement area of the drainage network is approximately 0.67 ha. The study area is located in the primary urban area known as Fuzhou City, which has low terrain and low latitude and a subtropical oceanic climate. Typhoons land directly on the downtown area twice a year, causing short-duration heavy rainfall, and the mean annual precipitation of the study area is $900-2100 \mathrm{~mm}$. Because of the rapid development of urbanization in recent years, the impermeable area of the study area has clearly increased, and the original design standard for the drainage system is low, with slow updating speed; when the precipitation is $37.602 \mathrm{~mm}$, the study area will experience sewer overflows.

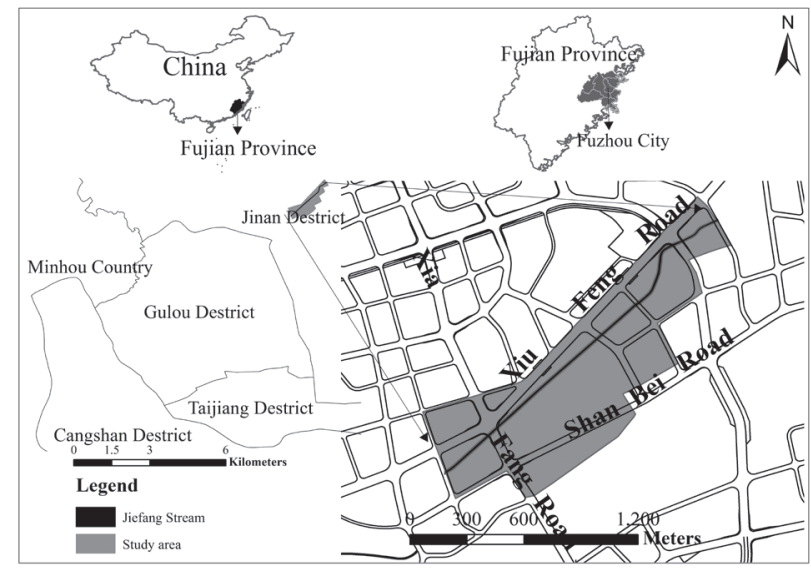

Fig. 1. Geographical information of the study area. 


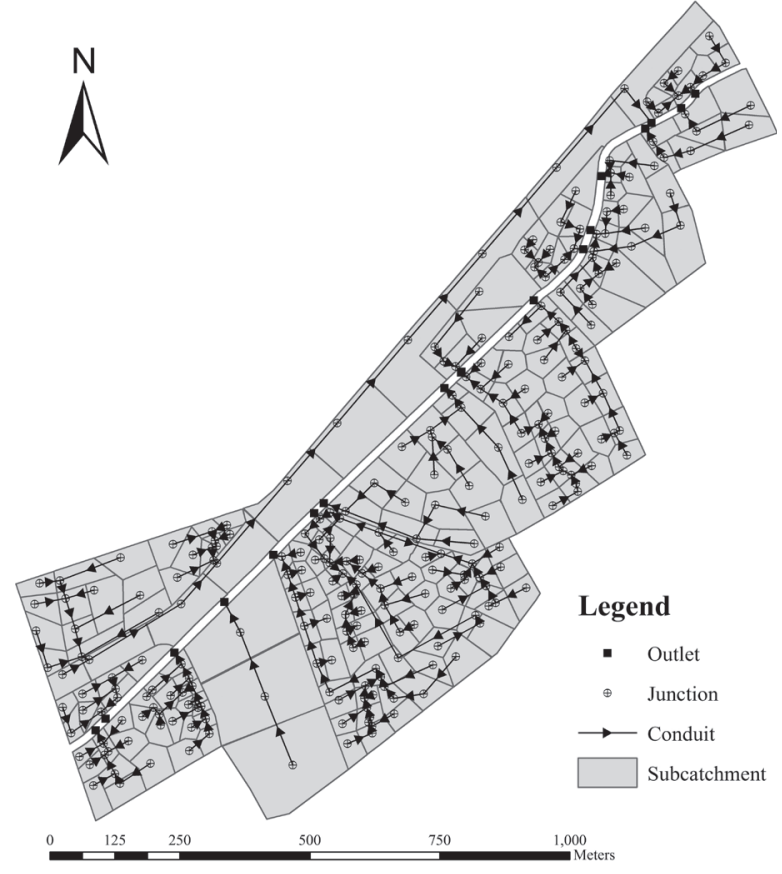

Fig. 2. Drainage system in the study area.

\section{Hydrological Model}

\section{Profile of PCSWMM Model}

PCSWMM is the comprehensive commercial software developed by Canada Computational Hydraulics International (CHI) based on EPA SWMM (stormwater management model), and it is widely applied to urban drainage and rainstorm management research. In addition to employing the same kernel program and functions as the SWMM model, the latest and most powerful geographic information system engine is combined and designed in the latest PCSWMM 2015. This system supports the coupling of the 1D/2D model, and the complete pollutant migration and rainfall runoff process can be simulated to provide decision-making advice for regional LID management [24-25]. The LID control module provided by the PCSWMM model can precisely simulate different types of LID control, such as control over retention, infiltration, and evaporation [24, 26-27]. At present, the PCSWMM model is widely used to evaluate the traditional drainage system and the rainfall flood management effect of the LID drainage system [28-30].

\section{Generalization of Study Area}

Based on the application requirements of the PCSWMM model and the actual situation of the study area, and combining information for the current stormwater pipes network in the study area provided by the Fuzhou Planning and Design Institute, the drainage systems in the study area have been divided into 263 manholes, 228 of which were chosen as water

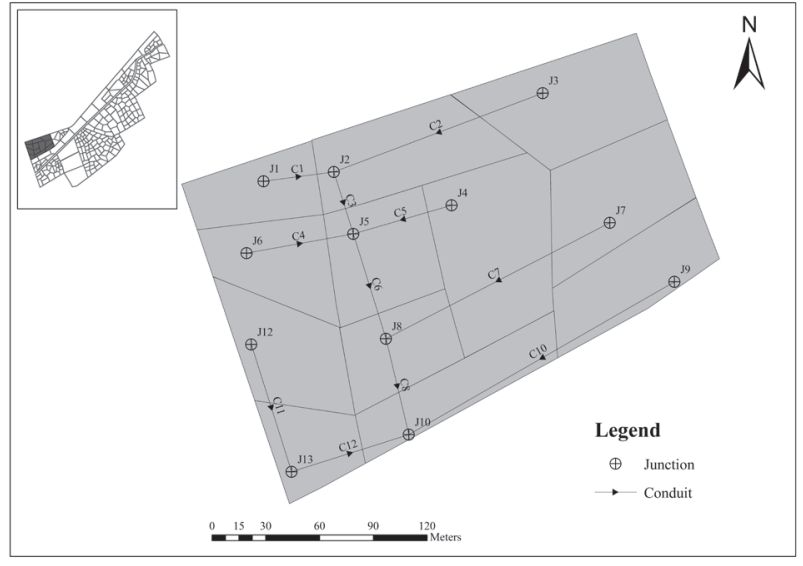

Fig. 3. Drainage system in the LID layout area.

outlets of the sub-catchments; there are also 263 stormwater pipes and 18 outfalls. The basin was generalized into 228 sub-streams based the basins classification function in the ArcGIS 10.3 hydrological analysis (the drainage system generalization of the study area is shown in Fig. 2). The community located in the northwestern part of the study area is most seriously affected by flood disasters, in which the rainfall intensity $\geq 4.5 \mathrm{~mm} / \mathrm{h}$ and waterlogging occurs; therefore, the community has taken as the research objective in this paper the simulation of rainfall flood reduction effects by using LID measures for the total area of $4.4 \mathrm{ha}$. The community is divided into 12 sub-catchments (S1-S12), 12 manholes, and 11 sewers (Fig. 3). Fig. 4 shows the land utilization classification for the community. The current land in the whole community is classified into 4 types based on the underlying surface type, namely the road, green space, water, and roofs, with area ratios of $43.08 \%$, $31.29 \%, 4.08 \%$, and $21.55 \%$, respectively.

\section{Choice of Hydrologic and Hydraulic Parameters}

The area, characteristic width, average slope and impermeable ratio of the sub-catchments in the study

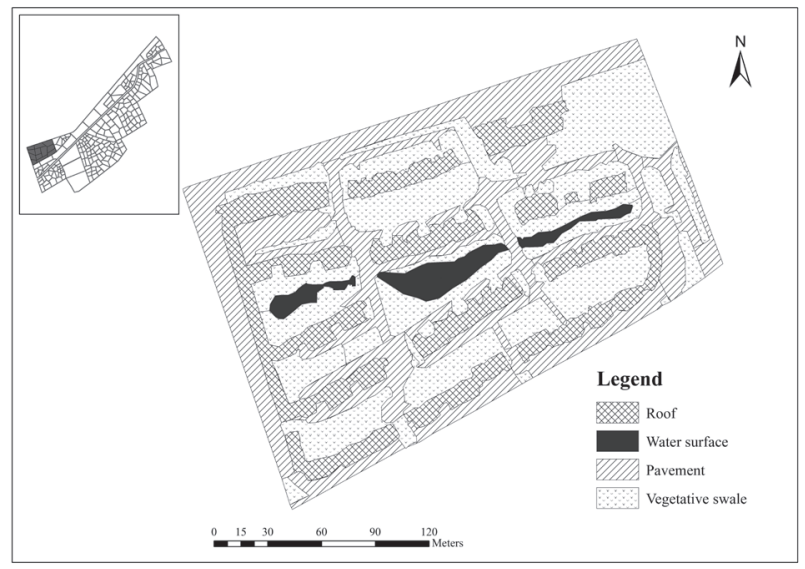

Fig. 4. Land use classification in the LID layout area. 
Table 1. The experience value of urban runoff coefficient.

\begin{tabular}{|c|c|c|}
\hline Regional situation & Impervious area percentage & Comprehensive runoff coefficient \\
\hline Dense building centre area & $>70$ & $0.6 \sim 0.8$ \\
\hline Relatively dense building residential area & $50 \sim 70$ & $0.5 \sim 0.7$ \\
\hline Low density building residential area & $30 \sim 50$ & $0.4 \sim 0.6$ \\
\hline Very low density building residential area & $<30$ & $0.3 \sim 0.5$ \\
\hline
\end{tabular}

Table 2. Value of uncertain model parameter.

\begin{tabular}{|c|c|c|c|c|c|c|c|}
\hline \multicolumn{2}{|c|}{ Depression storage quantity/mm } & \multicolumn{3}{|c|}{ Manning coefficient } & \multicolumn{3}{c|}{ Horton infiltration parameter } \\
\hline $\begin{array}{c}\text { Permeable } \\
\text { surface }\end{array}$ & $\begin{array}{c}\text { Impervious } \\
\text { surface }\end{array}$ & $\begin{array}{c}\text { Permeable } \\
\text { surface }\end{array}$ & $\begin{array}{c}\text { Impervious } \\
\text { surface }\end{array}$ & Pipeline & $\begin{array}{c}\text { Maximum } \\
\text { infiltration rate } \\
(\mathrm{mm} / \mathrm{h})\end{array}$ & $\begin{array}{c}\text { Minimum } \\
\text { infiltration rate } \\
(\mathrm{mm} / \mathrm{h})\end{array}$ & $\begin{array}{c}\text { Attenuation } \\
\text { coefficient } \\
\left(\mathrm{h}^{-1}\right)\end{array}$ \\
\hline 5.8 & 1.5 & 0.3 & 0.012 & 0.013 & 102 & 14 & 4 \\
\hline
\end{tabular}

area can be obtained by the land use type classification diagram and topographic map through a spatial analyst module of ArcGIS 10.3. The pipeline shape, pipe cross section size, offset value of pipeline starting and ending points, bottom elevation of the manholes, maximum depth of manhole, and others can be obtained from the drainage network information provided by the Fuzhou Planning and Design Institute. Uncertain parameters of the model are chosen primarily on the basis of the actual local situation, and in reference to the parameter list and recommended property values of the SWMM model user guide and the rational parameter values verified by researchers as default value [24, 27, 31-37]. This model draws on the parameter calibration method of urban rainfall runoff model raised by Liu [38] and He et al.
[39] to calibrate the primary parameters of the model. In calculating the simulative comprehensive runoff coefficient by using the peak runoff time as the time for the runoff coefficient simulation, the comprehensive flow coefficient was used in the design of the runoff pipe network, and therefore the corresponding rainfall return period is the recurrence interval stipulated by the current drainage standard. Thus, the rainfall return periods chosen for verification were $\mathrm{P}=1 \mathrm{a}, \mathrm{P}=2 \mathrm{a}$, and $\mathrm{P}=3 \mathrm{a}$. When the rainfall duration is $2 \mathrm{~h}$, the location of peak rainfall intensity is $r=4$ (Table 1 shows the experience comprehensive runoff coefficient of the catchment area obtained through querying the outdoor drainage design specification [40] and the urban drainage manual [41]). Table 2 shows the final verified uncertain

Table 3. LID layout schemes.

\begin{tabular}{|c|c|c|c|}
\hline $\begin{array}{c}\text { LID } \\
\text { measures }\end{array}$ & Introduction of LID measures & Construction contents & $\begin{array}{c}\text { Layout } \\
\text { area (ha) }\end{array}$ \\
\hline LID1 & $\begin{array}{l}\text { Permeable Pavement refers to engineering measures in which } \\
\text { impervious pavement are changed into porous pavement through } \\
\text { a variety of technical methods to reduce surface runoff directly. }\end{array}$ & $\begin{array}{l}\text { Refit the hard, impervious pavement } \\
\text { of all sub-catchment areas in the } \\
\text { community into porous pavement. }\end{array}$ & 1.90 \\
\hline LID2 & $\begin{array}{l}\text { Vegetative Swales refer to the landscape surface ditch drainage } \\
\text { system with a dual runoff control function. In addition to reducing } \\
\text { peak rainfall runoff discharge through storage, it can also remove } \\
\text { most suspended solids in rainfall runoff. }\end{array}$ & $\begin{array}{l}\text { Refit common greenbelt of all sub- } \\
\text { catchment areas } \\
\text { in the community into } \\
\text { vegetative swale. }\end{array}$ & 1.23 \\
\hline LID3 & $\begin{array}{l}\text { Green roof is a multi-layered system primarily composed } \\
\text { of multilayer materials such as vegetation layer, soil layer, } \\
\text { drainage layer, waterproof layer, etc. Through the storage of medium } \\
\text { and through plant evaporation to achieve the retention of runoff, } \\
\text { thereby reducing the surface runoff, cutting down on peak discharge } \\
\text { and further improving runoff quality. }\end{array}$ & $\begin{array}{l}\text { Refit roofs of all sub-catchment } \\
\text { areas in the community into green } \\
\text { roofs. }\end{array}$ & 0.95 \\
\hline LID12 & LID1 \& LID2 combination measure & \multirow{4}{*}{$\begin{array}{l}\text { Layout area and settings of LID } \\
\text { combination measure are } \\
\text { consistent with signal layout. }\end{array}$} & 3.13 \\
\hline LID13 & LID1 \& LID3 combination measure & & 2.85 \\
\hline LID23 & LID2 \& LID3 combination measure & & 2.18 \\
\hline LID123 & LID1 \& LID2 \& LID3 combination measure & & 4.08 \\
\hline
\end{tabular}


Table 4. Summary of LID characteristics.

\begin{tabular}{|c|c|c|c|c|}
\hline & Parameters & Permeable Pavement & Vegetative Swale & Green roof \\
\hline \multirow{4}{*}{ Surface } & Berm Height (millimetres) & 0 & 200 & 150 \\
\hline & Vegetation Volume (fraction) & 0 & 0.10 & 0.10 \\
\hline & Surface Roughness (Manning n) & 0.01 & 0.32 & 0 \\
\hline & Swale Side Slope (length/ litre) & - & 5 & - \\
\hline \multirow{5}{*}{ Pavement } & Thickness (millimetre) & 100 & - & - \\
\hline & Void Ratio (interspace/solid) & 0.15 & - & - \\
\hline & Impervious Surface Fraction & 0 & - & - \\
\hline & Permeability(millimetre/hour) & 200 & - & - \\
\hline & Clogging Factor & 0 & - & - \\
\hline \multirow{4}{*}{ Storage } & Thickness (millimetre) & 450 & - & - \\
\hline & Void Ratio (interspace/solid) & 0.75 & - & - \\
\hline & Infiltration Rate (millimetre/ hour) & 400 & - & - \\
\hline & Clogging Factor & 0 & - & - \\
\hline \multirow{7}{*}{ Soil } & Thickness (millimetre) & - & - & 150 \\
\hline & Porosity (Volume fraction) & - & - & 0.46 \\
\hline & Field Capacity (Volume fraction) & - & - & 0.2 \\
\hline & Wilting point (Volume fraction) & - & - & 0.12 \\
\hline & Conductivity (millimetre/ hour) & - & - & 3.30 \\
\hline & Conductivity Slope & - & - & 15 \\
\hline & Suction head (millimetre) & - & - & 88.9 \\
\hline \multirow{3}{*}{ Drainage mat } & Thickness (millimetre) & - & - & 30 \\
\hline & Void Fraction & - & - & 0.5 \\
\hline & Manning roughness & - & - & 0.1 \\
\hline
\end{tabular}

parameter values. The runoff coefficient simulation values of three precipitation processes are $0.65,0.70$, and 0.73 , meeting the requirements for a comprehensive runoff coefficient (the comprehensive runoff coefficient in a dense building center area is $0.6 \sim 0.8$ ); therefore, the calibration parameter set has a relatively good adaptive capacity within this research and can be used for the simulation analysis of the area. This research on the rainfall infiltration process adopts the Horton equation to make simulations. The Horton model primarily describes the relationships of the infiltration rate with the change in rainfall time, adapting to the scenario of a small drainage basin with a few undetermined parameters. The runoffyield model for overland runoff is divided into 3 areas, i.e., the impervious surface area with the depression storage quantity, the impervious surface area without a depression storage quantity, and the permeable surface area to make separate calculations. Calculating the confluence of overland runoff involves the adoption of a nonlinear reservoir model, and the hydraulic model for simulating the flow routing of a drainage system adopts the dynamic wave model [26-27].

\section{LID Parameter Setting}

This paper analyzed 8 different land layout scenarios that make up the current land layout scenario (without adopting any LID measures) and 7 LID layout scenarios in Table 3. Each LID land layout scenario will be used in the following research to analyze the control effect of different LID measures on the runoff water quantity and quality under different rainfall characteristics (Tab.3). The parameter settings of different LID measures primarily refer to the recommended value in the PCSWMM user's manual and reference value given by the relevant scholars [33-34, 36, 42-49]. See Table 4 for details of LID parameter settings.

\section{Water Quality Parameter Settings}

Suspended solids (SS) are common pollutants with high concentration in urban runoff. Therefore, this paper used SS as a research focus, using PCSWMM pollutant modules and land use modules, pollutant accumulation modules, and pollutant washoff modules to perform 
Table 5. SS simulation parameters of different underlying surfaces.

\begin{tabular}{|c|c|c|c|c|c|}
\hline & $\begin{array}{c}\text { Maximum possible } \\
\text { build-up (kg/ha) }\end{array}$ & $\begin{array}{c}\text { Days to reach half the } \\
\text { maximum build-up (d) }\end{array}$ & $\begin{array}{c}\text { Washing } \\
\text { coefficient }\end{array}$ & $\begin{array}{c}\text { Washing } \\
\text { exponent }\end{array}$ & $\begin{array}{c}\text { Cleaning removal } \\
\text { rate (\%) }\end{array}$ \\
\hline Road Surface & 120 & 10 & 0.008 & 1.8 & 20 \\
\hline Roof & 50 & 10 & 0.007 & 1.8 & 0 \\
\hline Greenbelt & 30 & 10 & 0.005 & 1.4 & 0 \\
\hline
\end{tabular}

Table 6. Rainfall scenarios of different rainfall return periods.

\begin{tabular}{|c|c|c|c|c|c|c|c|c|}
\hline Rainfall return periods & $\mathrm{P}=0.5 \mathrm{a}$ & $\mathrm{P}=1 \mathrm{a}$ & $\mathrm{P}=2 \mathrm{a}$ & $\mathrm{P}=5 \mathrm{a}$ & $\mathrm{P}=10 \mathrm{a}$ & $\mathrm{P}=20 \mathrm{a}$ & $\mathrm{P}=50 \mathrm{a}$ & $\mathrm{p}=100 \mathrm{a}$ \\
\hline Precipitation (mm) & 37.60 & 49.85 & 62.09 & 78.28 & 90.53 & 102.72 & 118.96 & 131.21 \\
\hline Rainfall intensity (mm/h) & 18.80 & 24.92 & 31.05 & 39.14 & 45.26 & 51.36 & 59.48 & 65.61 \\
\hline Rainfall duration (h) & \multicolumn{10}{|c|}{0.4} \\
\hline location of peak rainfall intensity & \multicolumn{10}{|c|}{5} \\
\hline Time step (min) & \multicolumn{10}{|c|}{4} \\
\hline Simulated time (h) & \multicolumn{10}{|c|}{} \\
\hline
\end{tabular}

an SS pollution load simulation of rainfall runoff in the northwest community. The influences of different land use situations on the pollutants accumulation and washoff are taken into consideration, with domestic and overseas-relevant research sources [35, 50-51], a saturation function model is adopted to simulate the accumulation process of the surface pollutants in this paper. This model can simulate the accumulation of surface pollutants well, and the parameters that must be input include the maximum accumulation and halfsaturation constant (half-saturation accumulation time). A washoff model for earth's sub-catchment pollutants will involve an exponential function model, and it can be more objective to show the change of the pollutant's scour with the change of rainfall duration. When using the washoff model, the model parameters must be input, including the washing coefficient, washing index, and cleaning removal rate. On the basis of the actual status of the study area and the combination of research results of similar areas and pertinent literature [50, 52-54], the water quality parameters of this study area have been determined and are shown in Table 5. The removal rates of vegetative swale, rain gardens, permeable pavement, and green roofs in this research on the SS load of runoff are $60 \%, 80 \%, 90 \%$, and $80 \%$, respectively. On the basis of the actual status of the study area, the street cleaning intervals in the model are determined as 1 day, and the cleaning removal efficiency of surface accumulation pollutants is $70 \%$. The simulated early drought days are 7, assuming that the SS contained in the runoff is at $10 \mathrm{mg} / 1$ [53-55].

\section{Design Storms}

In this study, the effects of LID on rainfall runoff were stimulated under various types of storm events. The storm events can be designed according to the relationship of rainfall intensity-duration-frequency in Fuzhou [56], which is described as below:

$$
q=\frac{3819.59(1+0.8161 \lg P)}{(t+24.4563)^{0.8062}}
$$

...where $\mathrm{q}$ is the mean rainfall intensity within time $\mathrm{t}$, $\mathrm{L} /(\mathrm{s} \cdot \mathrm{ha})$; $\mathrm{t}$ is the rainfall duration, in min; and $\mathrm{P}$ is the rainfall return period, a. The Chicago precipitation process line model (CHM method) was adopted to create

Table 7. Rainfall scenarios for different rainfall durations.

\begin{tabular}{|c|c|c|c|c|c|c|c|c|}
\hline Rainfall durations & $1 \mathrm{~h}$ & $1.5 \mathrm{~h}$ & $2 \mathrm{~h}$ & $2.5 \mathrm{~h}$ & $3 \mathrm{~h}$ & $3.5 \mathrm{~h}$ \\
\hline Precipitation (mm) & \multicolumn{5}{|c|}{90.53} \\
\hline Rainfall intensity (mm/h) & 90.53 & 60.35 & 45.26 & 36.21 & 30.18 & 25.87 \\
\hline location of peak rainfall intensity & \multicolumn{5}{|c|}{0.4} & 3 & 7 \\
\hline Time step (min) & 3 & 3 & 3 & 5 & 3 \\
\hline Simulated time (h) & \multicolumn{5}{|c|}{4} \\
\hline
\end{tabular}


Table 8. Rainfall scenario of different locations of peak rainfall intensity.

\begin{tabular}{|c|c|c|c|c|c|c|c|c|c|}
\hline location of peak rainfall intensity & 0.1 & 0.2 & 0.3 & 0.4 & 0.5 & 0.6 & 0.7 & 0.8 & 0.9 \\
\hline Rainfall return period & \multicolumn{9}{|c|}{$\mathrm{P}=10 \mathrm{a}$} \\
\hline Rainfall duration (h) & \multicolumn{9}{|c|}{2} \\
\hline Rainfall intensity $(\mathrm{mm} / \mathrm{h})$ & \multicolumn{9}{|c|}{45.26} \\
\hline Time step (min) & \multicolumn{9}{|c|}{5} \\
\hline Simulated time (h) & \multicolumn{9}{|c|}{4} \\
\hline
\end{tabular}

the rainfall scenario [41, 57]. Design storms are derived according the rainfall intensity-duration-frequency equation and time-to-peak ratio $r$ (where $0<\mathrm{r}<1$ ), which is defined as the ratio of the time before the peak intensity to the total duration. The variable $\mathrm{r}$ describes the location of peak rainfall intensity: the bigger the $r$ value, the further the peak intensity from rainfall starting time.

Three groups of storms were designed in the research. Group I: the storm events have different return periods (0.5-, 1-, 2-, 5-, 10-, 20-, 50-, and 100-year), and the corresponding total rainfall amounts range from 37.60 to $131.21 \mathrm{~mm}$. They all have the same rainfall duration $(2 \mathrm{~h})$ and location of peak rainfall intensity $(\mathrm{r}=0.4)$ (Table 6). Group II: the storm events have different rainfall durations (1-,1.5-, 2-, 2.5-, 3-, and 3.5-hour). They have the same rainfall amount $(90.53 \mathrm{~mm})$ and location of peak intensity $(\mathrm{r}=0.4)$ (Table 7). Group III: the storm events have different time-to-peak ratio $\mathrm{r}(0.1,0.2,0.3$, $0.4,0.5,0.6,0.7,0.8$, and 0.9), and they have the same rainfall return period (10 year) and rainfall duration $(2 \mathrm{~h})$ (Table 8). The aims of Group I, Group II, and Group III are to investigate how the effect of LID designs in terms of urban rainwater runoff is affected by rainfall return period, rainfall duration, and location of peak intensity, respectively.

\section{Results and Discussion}

Rainfall flood simulation of the study area under the current land layout scenario

Rainfall runoff in the base case scenario is simulated under a different rainfall return period. The simulation results indicate that: (1) With the increase in the rainfall return period, the runoff volume and infiltration capacity in the study area increased accordingly, the impermeable area of the study area is relatively large result in the detention storage capacity for runoff is small; (2) With the increase of precipitation, the surface storage quantity is relatively small, primarily because the retention effect of hard ground is poor; and (3) The runoff coefficient increases with the rainfall return period, which explains that under almost no change in the final storage quantity in the sub-catchment, with increasing precipitation, the increase in runoff volume is far greater than the increased quantity of infiltration (Fig. 5).

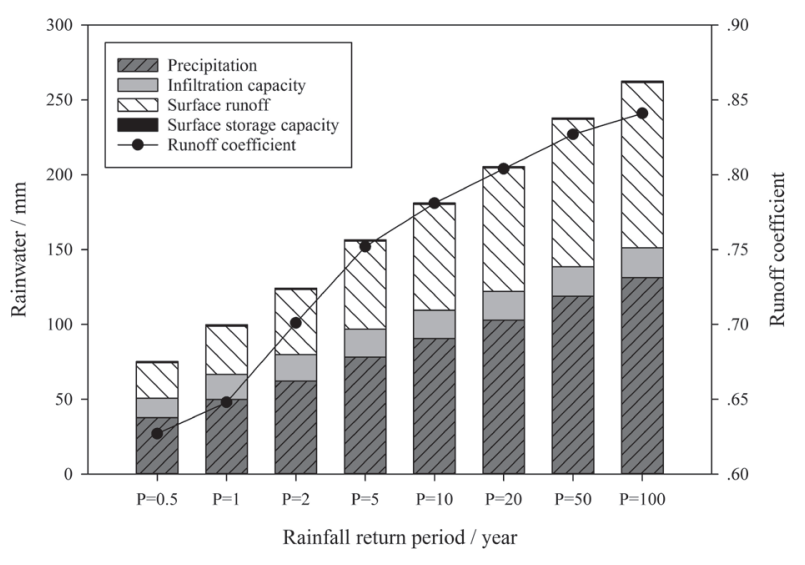

Fig. 5. Simulation of rainfall flood in the study area under different rainfall return periods.

The northwest community in the study area (Fig. 3) is the most affected, when $\mathrm{P}=0.5$ a waterlogging nodes start to appear, and when $\mathrm{P}=100$ a the waterlogging nodes cover $75 \%$ of the manhole quantity of the community. Therefore, this paper will further study the rainfall flood situation of the northwest community under different LID layout scenarios.

\section{Effects of Different Rainfall Return Periods}

The effect of LID layout scenarios on runoff and SS is analyzed by comparing the base case with various LID layout scenarios. And the effect can be measured by runoff and SS reduction, which is defined as the difference in total runoff volume and SS load of overland runoff during a storm event between the base case and a LID layout scenario. The effect in Group I storm events with different rainfall return periods is first stimulated, and results obtained are shown in Figs 6-9.

About the runoff volume reduction, the results indicate that: (1) In the single LID layout scenario, the permeable pavement has a strong controlling effect on the total runoff volume for its high detention storage capacity and the largest layout area in the northwest community. A green roof has relatively poor reduction effects on runoff because the layout area is small. The reduction effect of vegetative swale on runoff is worst in the single LID scenarios, because the detention storage capacity is relatively small. (2) In the combined 
LID layout scenarios, the control effect of the LID23 is worse than LID1 measure caused by the detention storage capacity of the green roof and the vegetative swale are not as high as that of permeable pavement. (3) When the rainfall intensity exceeds a certain range, the control effect of all LID layout scenarios on the rainfall runoff will gradually decrease. This trend is primarily explained because with the increase in precipitation, the increase of runoff volume is much larger than that of LID water storage capacity. The vegetative swale, permeable pavement, and green roof have a certain detention storage capacity; when the precipitation exceeds its detention storage capacity, the water will overflow and become runoff. In addition, the high rainfall intensity will cause time contraction of runoff concentration, and even produce runoff when infiltration and retention do not reach saturation. Therefore, the control effects of LID on rainfall runoff have a certain scope, which will be more obvious at the time of a low-rainfall return period.

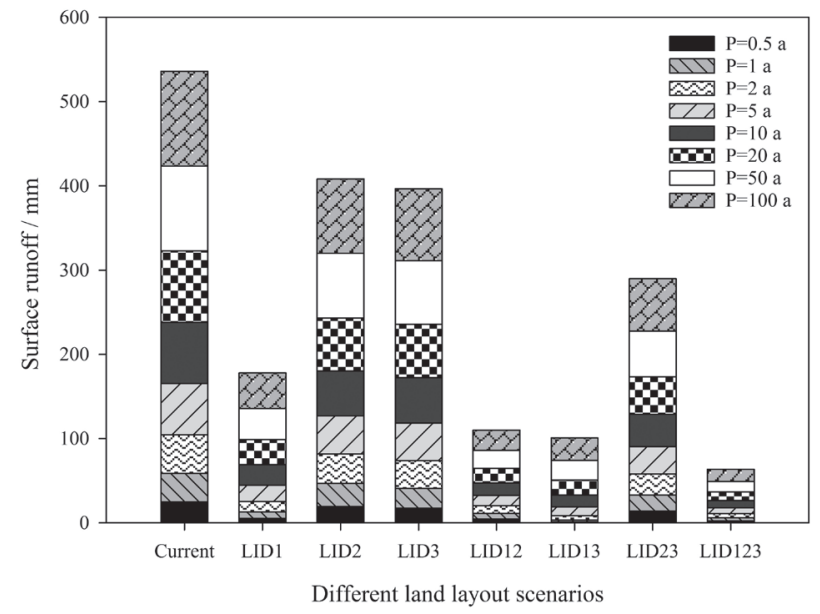

Fig. 6. Surface runoff of different land layout scenarios under different rainfall return periods.

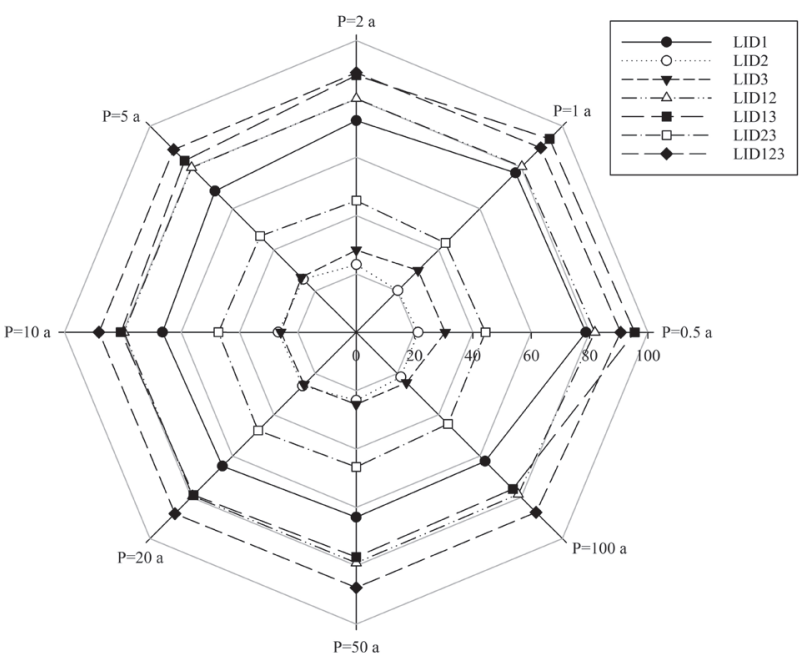

Fig. 7. Percentage reduction in surface runoff of different LID layout scenarios under different rainfall return periods.
About the SS load reduction, the results indicate that: (1) The amplification of the runoff SS loads of LID2, LID3, and LID23 LID layout scenarios in this research are relatively high during the low rainfall return period. This finding is primarily explained because the surface runoff of these LID layout scenarios is relatively large, and the washed out quantity of surface pollutants is relatively high when precipitation is relatively small. (2) After laying LID measures, the SS load in runoff clearly decreases. The reduction effect of the LID123 measure on SS loads is the best, with the reduction rate reaching over 97\%; the reduction effect of the LID2 measure is the worst, with reduction rates of $17-31 \%$. The layout area of the green roof is smaller than the area of the vegetative swale; however, the reduction effect on overland runoff $\mathrm{SS}$ is better than that of the vegetative swale, which is primarily because the removal rate of green roofs on overland runoff SS is stronger than that of the vegetative swale. (3) When the precipitation is low, the LID control

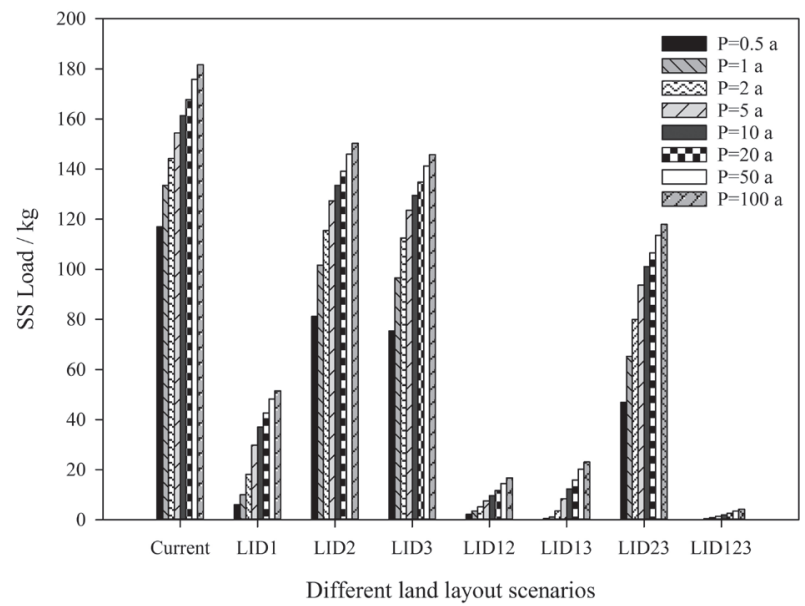

Fig. 8. SS load of different land layout scenarios under different rainfall return periods.

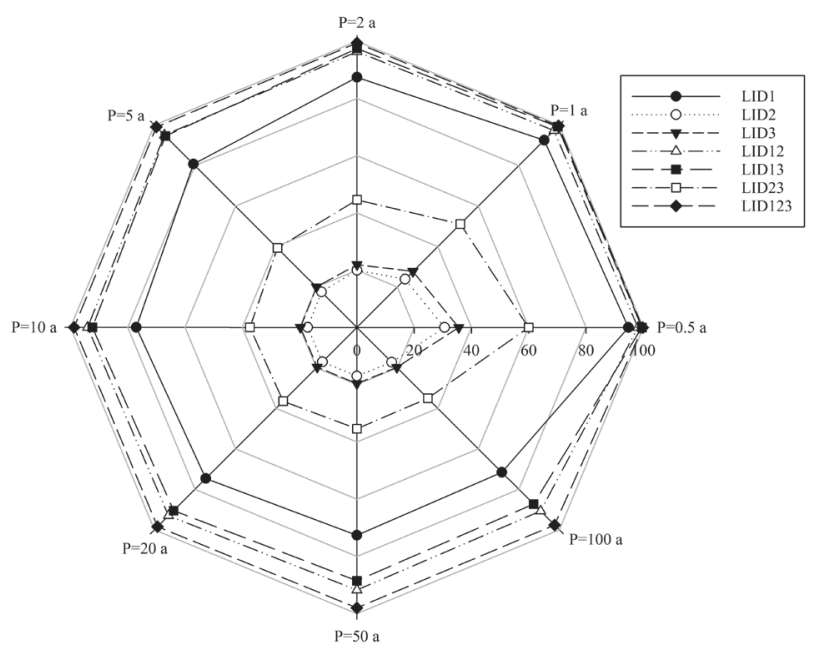

Fig. 9. Percentage reduction in SS load of different LID layout scenarios under different rainfall return periods. 
measure has a better control effect on runoff SS, which indicates that LID measures have a certain range for the control of overland runoff pollutants.

\section{Effects of Different Rainfall Durations}

The effects of LID layout scenarios on reduction of runoff and SS under Group II storm events with different rainfall durations are shown in Figs 10-13.

About the runoff volume reduction, the results indicate that: (1) The reduction effect on the surface runoff is obvious, with the increase in rainfall duration after LID measures set by the research community. After taking LID measures, all LID layout scenarios have a certain reduction effect on the surface runoff for different rainfall durations. The reduction effect of the LID123 measure is the best in the LID combined measures. The reduction effect of the permeable pavement is the best in the LID single measures. (2) The LID measures have a relatively obvious reduction effect under a long rainfall

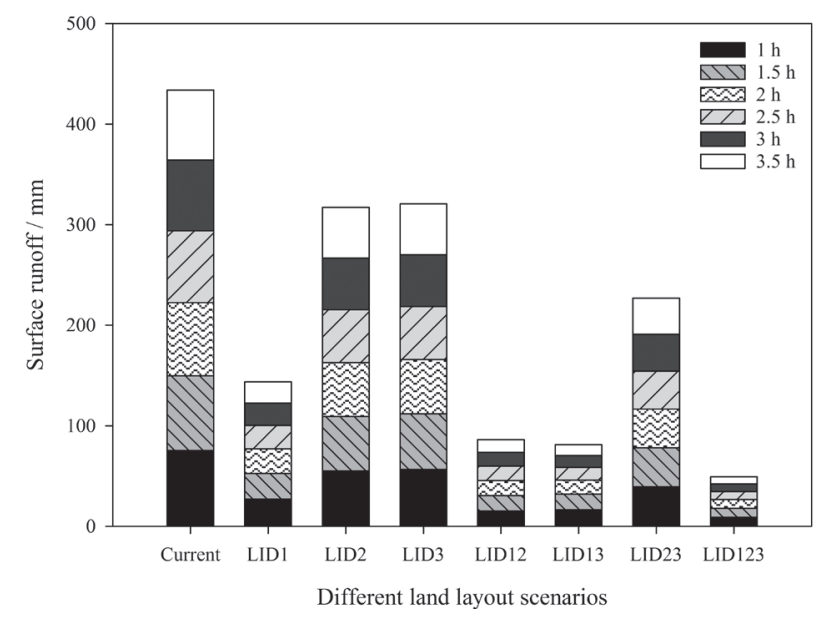

Fig. 10. Surface runoff of different land layout scenarios under different rainfall durations.

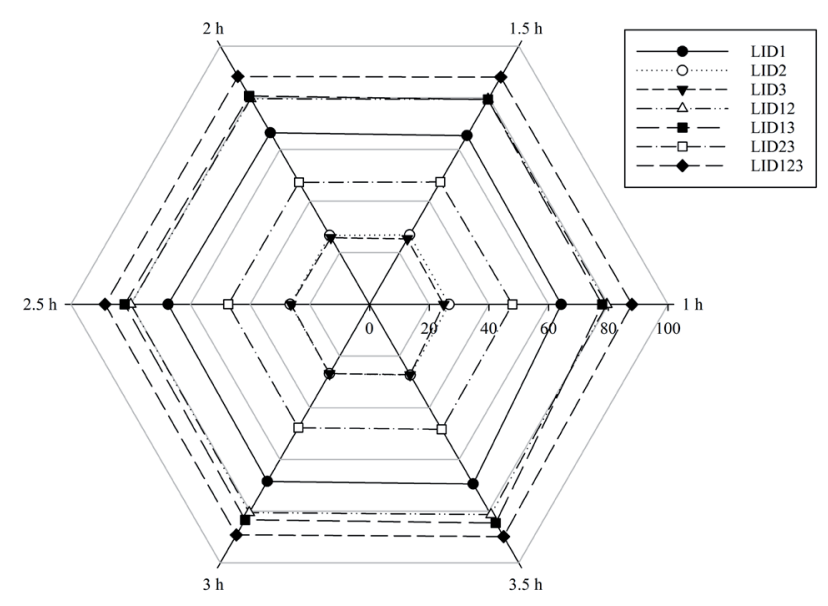

Fig. 11. Percentage reduction in surface runoff of different LID layout scenarios under different rainfall durations. duration, and the control effect of the LID combined measure on the total runoff volume is better than that of the single LID measure in the combination, it is the optimal choice to meet the need only to control the total runoff volume.

About the SS load reduction, the results indicate that: (1) The rainfall intensity decreases with the increased rainfall duration, which reduced the washing degree of overland runoff on pollutants; and the more pollutants held back by LID measures, the more the SS load of rainfall runoff in the study area is reduced. (2) The LID123 layout scenario has the best effect on the SS load of the runoff with its reduction rate over $98 \%$, when the rainfall duration is relatively long and the SS load in the runoff is approximately zero. The reduction effects of LID12 and LID13 layout scenarios were in second place, with reduction rates between $89 \%$ and $95 \%$; the vegetative swale had the worst reduction effect at approximately $17 \%$. Different LID layout scenarios have better reduction effects over long rainfall durations.

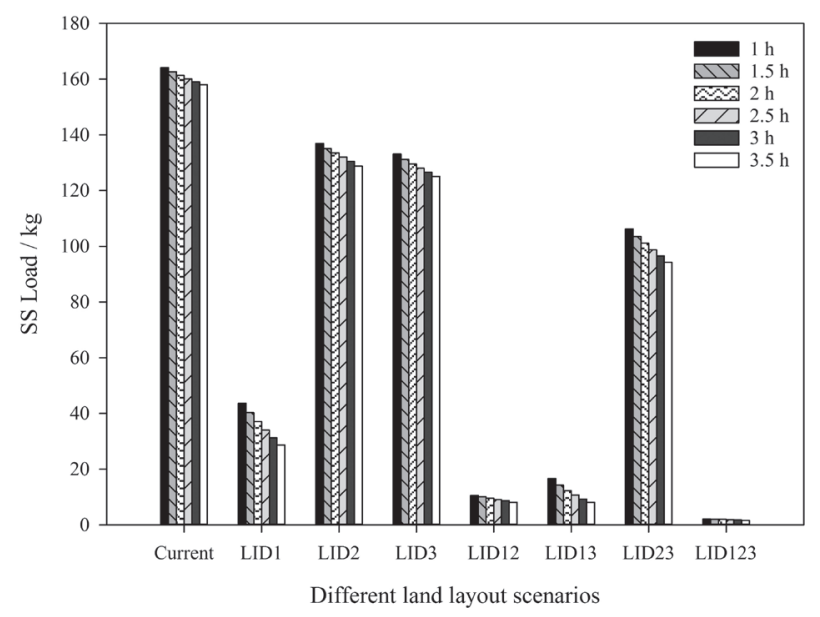

Fig. 12. SS load of different LID land layout scenarios under different rainfall durations.

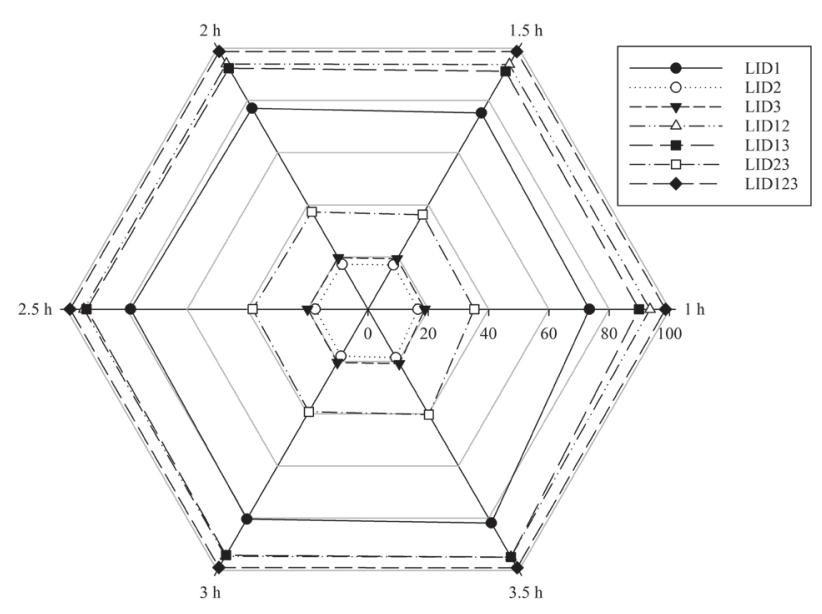

Fig. 13. Percentage reduction in SS load of different LID layout scenarios under different rainfall durations. 


\section{Effects of Different Locations of Peak Rainfall Intensity}

The effects of LID layout scenarios on reduction of runoff and SS in under the Group III storm events with different locations of peak rainfall intensity (r) are shown in Figs 14-17.

About the runoff volume reduction, the results indicate that: (1) The surface runoff tends to increase first and then decrease but without a large difference. (2) In this research, the changes in locations of peak rainfall intensity have almost no influence on the total surface runoff volume in LID layout community, and the runoff reduction effect of all the LID layout scenarios is not affected. This finding occurs because when the rain peak changes, the rainfall intensity remains almost unchanged, and the total precipitation and peak rainfall remain almost unchanged; the peak position then does not have a decisive effect on overland runoff. (3) Under the rainfall conditions of different locations of peak rainfall intensity, the LID123 layout scenario has the best

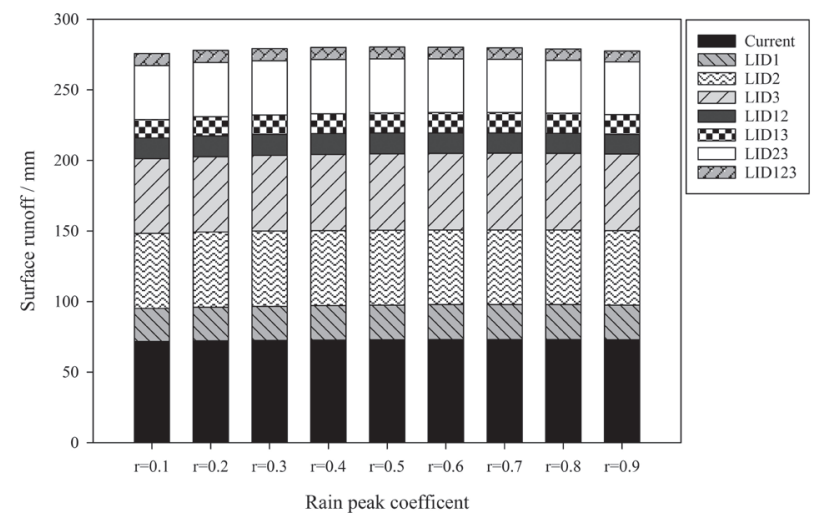

Fig. 14. Surface runoff of different land layout scenarios under different rain peak coefficients.

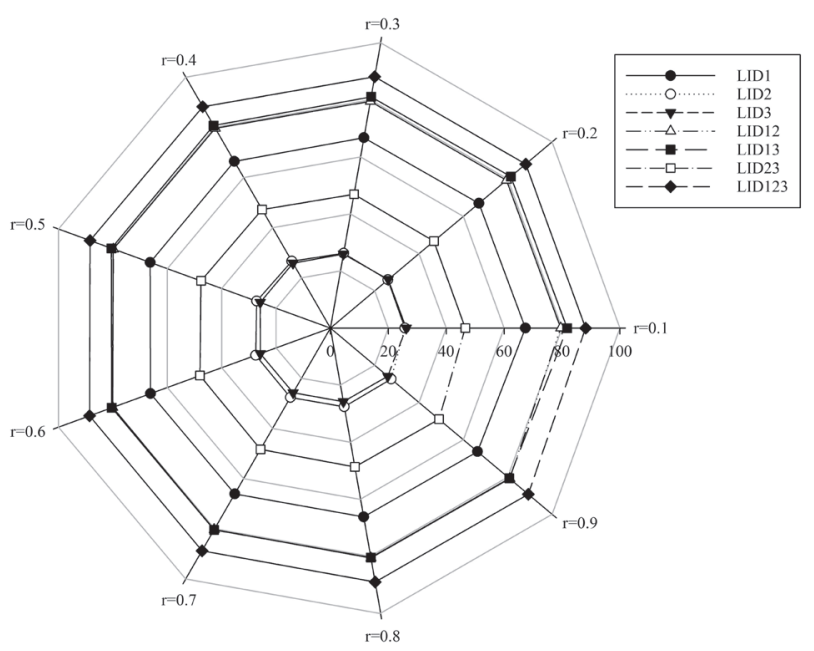

Fig. 15. Percentage reduction in surface runoff of different LID layout scenarios under different rain peak coefficients. reduction effect on the runoff volume with a reduction rate of approximately 89\%; the LID12 and LID13 layout scenarios take second place, with the reduction rate at approximately $80 \%$. The reduction effect of the green roof is the worst, with a reduction rate of approximately $26 \%$.

About the SS load reduction, the results indicate that: (1) As in the change trend for surface runoff under different locations of peak rainfall intensity, the SS loads in runoff in the community area under different land layout scenarios tend to increase first and then decrease. The change of locations of peak rainfall intensity may cause the pollutants that are washed of the surfaces to increase at an earlier stage in the rain peak, and the pollutants that are held back on the surface are decreased during the later period and finally lead the pollutant load in the runoff to increase. (2) If the locations of peak rainfall intensity are set too back, then the runoff from the earlier stage has been discharged for the most part and the runoff volume that accumulated on the surface is reduced. When the rain peak comes, the overland runoff

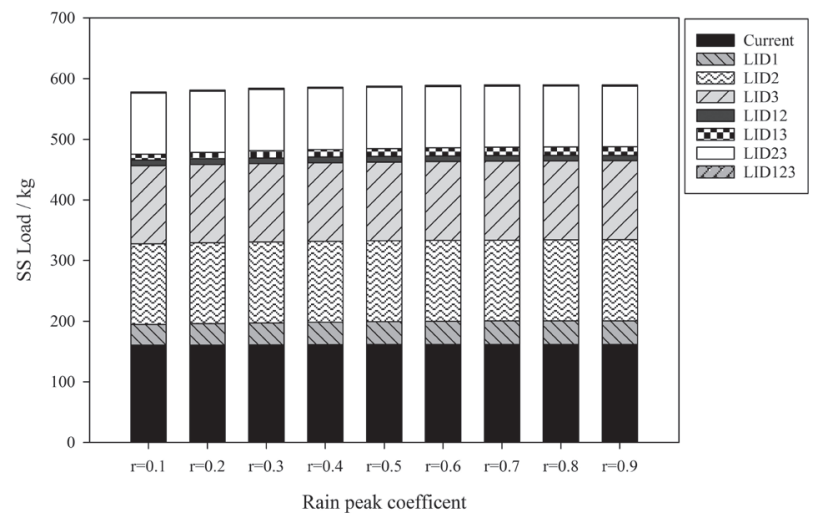

Fig. 16. SS load of different land layout scenarios under different rain peak coefficients.

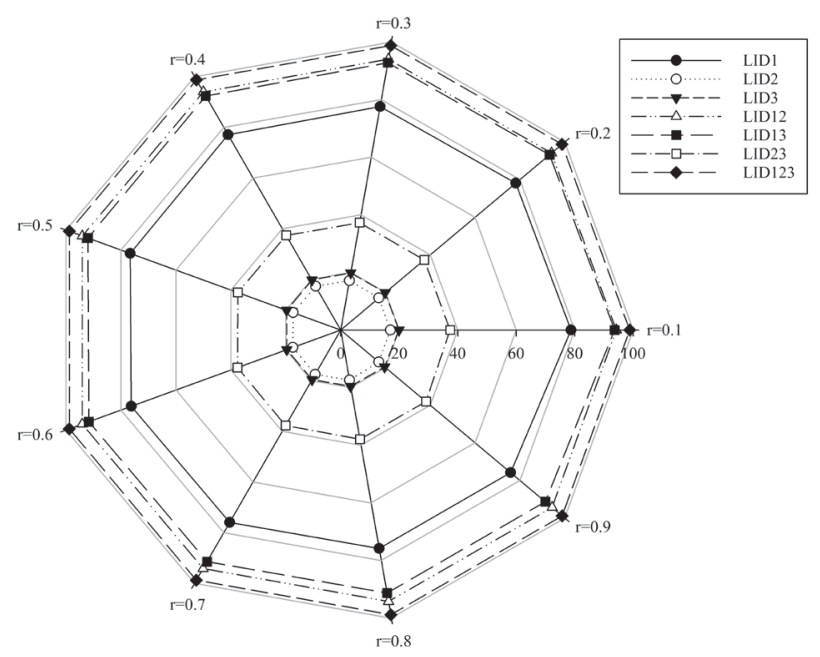

Fig. 17. Percentage reduction in SS load of LID layout scenarios under different rain peak coefficients. 
is relatively low and the washing capacity of the runoff on pollutants is relatively weak. In addition, the washing time of the rain peak on the surface is shortened, and the pollution load in the runoff will be reduced. (3) However, the variation amplitude of SS loads in the runoff of different rainfall patterns is relatively small, and the influence of peak rain positions on the reduction effect of different LID layout scenarios in terms of pollutant loans is not large. This is explained by the fact that the changes in locations of peak rainfall intensity do not change the rainfall intensity, the total precipitation, and the rainfall peak remains unchanged; there is not an apparent change to the total washed-off quantity of SS by rainfall runoff in the research community.

\section{Conclusions}

Our paper analyzed the impacts of LID on urban rainfall runoff in a high-density residential catchment in China, where various LID layout scenarios are considered in combination with a conventional drainage system for stormwater management. The main results obtained are summarized below.

Different LID layout scenarios have certain control effects on the output of overland runoff and SS load capacity in runoff under different rainfall characteristics. In a single LID layout scenario, permeable pavement has the most impact on runoff and SS load under different rainfall characteristics, which is explained by the largest layout area $(44.6 \%)$, and it has the most effective storage capacity $(450 \mathrm{~mm})$. A green roof has a better control effect on the runoff SS load capacity but a worse control effect on runoff than vegetative swale. In the combined scenario, the control effect of the LID123 layout scenario is the best in the LID combined measures. The LID13 layout scenario has a better reduction effect on the overland runoff water quantity and quality than the LID12 layout scenario when the rainfall return period is relatively low $(\mathrm{P} \leq 10 \mathrm{a})$, but a worse reduction effect than that of the LID12 layout scenario when the rainfall intensity is relatively high, which means that the LID13 layout scenario is more sensitive to rainfall intensity than the LID12 layout scenario. Different LID layout scenarios have better reduction effects on the surface runoff volume and SS loan capacity during smaller rainfall return periods and longer rainfall duration storms, and the influence of changes on rain peaks position on the reduction effect is not significance. We would consider more the reduction effect of LID layout scenario on the total runoff volume to relieve rainfall flood disasters. In addition, there are limitations in the underlying surface type of the community.

This research shows that the green infrastructure of LID has very good prospects for solving urban rainfall flood issues, but the reduction effects of combined green and grey infrastructures has not been discussed. The relevant studies show that a green-grey infrastructure has an optimal effect on the reduction of rainfall floods. Although LID measures have been developed rapidly in China, they are not cohesive with current municipal facilities. Many LID projects in built-up areas place too much emphasis on the reduction and control of the drainage volume and peak flow within the development area, and their joining with municipal sewers that have been established is neglected, which cause the original field storm sewer to not be fully used. In future research, the combination of grey and green infrastructure will be enhanced, and LID measures will be combined with the local available runoff control measures more systematically and organically to engage in the sustainable development of the area. LID measures should be combined with the local realities more rationally to make full use of space and fields for optimal control effects. The emphasis will generally be placed on a combination with large-scale layout such as urban planning, landscape planning, and more to coordinate all the technical measures from the macro-perspective and bring the comprehensive benefits of all the engineering techniques into full play.

\section{Acknowledgements}

This study was financed by the Scientific Research Project of Fuzhou University (grant No. 510354). The authors are grateful to Tianjin Lonwin Technology Co. Ltd. for PCSWMM software support and Fuzhou Planning Design and Research Institute for their generous assistance in data collection.

\section{Conflict of Interest}

The authors declare no conflict of interest.

\section{References}

1. EUGENIA K., MING C. Impact of urbanization and landuse change on climate. Nature. 423 (6939), 528, 2003.

2. CHUNG E.S., PARK K., LEE K.S. The relative impacts of climate change and urbanization on the hydrological response of a Korean urban watershed. Hydrol. Process. 25 (4), 544, 2011.

3. LAFONTAINE J.H., HAY L.E., VIGER R.J., REGAN R.S., MARKSTROM S.L. Effects of Climate and Land Cover on Hydrology in the Southeastern U.S.: Potential Impacts on Watershed Planning. J Am Water Resour As. 51 (5), 1235, 2015.

4. VALIPOUR M. Long-term runoff study using SARIMA and ARIMA models in the United States. Meteorological Applications. 22 (3), 592, 2015.

5. VALIPOUR M., SINGH V.P. Global experiences on wastewater irrigation: Challenges and prospects. In: Balanced Urban Development: Options and Strategies for Liveable Cities., Springer; 289, Germany, 2016.

6. VALIPOUR M. Critical areas of Iran for agriculture water management according to the annual rainfall. European Journal of Scientifc Research. 84 (4), 600, 2012. 
7. LIU Z.H., WANG Y.G., LI Z.G., JIAN P. Impervious surface impact on water quality in the process of rapid urbanization in Shenzhen, China. Environmental earth sciences. 68 (8), 2365, 2013

8. BORRIS M., VIKLANDER M., GUSTAFASSON A.M., MARSALEK J. Simulating future trends in urban stormwater quality for changing climate, urban land use and environmental controls. Water science and technology: a journal of the International Association on Water Pollution Research. 68 (9), 2082, 2013.

9. SUN G.E., CALDWELL P. Impacts of urbanization on stream water quantity and quality in the United States. Water Resources Impact. 17 (1), 17, 2015.

10. CHE S.Q., XIE C.K., CHEN D., YU B.Q. Development and Constructive Approaches for Theories and Technologies of Sponge City System. Chinese Landscape Architecture. 31 (6), 11, 2015

11. XIE J. Discussion on the necessity of building corpus city. Shanxi Architecture. 41 (25), 194, 2015.

12. XU Z.Q. Policy evolution and local practice of sponge cities with Chinese characteristics. Urban Management. 24 (1), 49, 2015

13. YANG Y., LIN G. A Review on Sponge City. South Architecture. (3), 59, 2015.

14. DAVIS A.P. Green engineering principles promote low impact development. Environmental science \& technology. 39 (16), 338A, 2005.

15. WANG J. Stormwater management in green building on the base of low impact development. Industrial Construction. 39 (3), 123, 2009

16. ZHANG S.F., SONG S.H., WANG J.Y. Low Impact Development (LID): The Landscape Approach of Solving the Urban Stormwater Problems. Huazhong Architecture. (5), 83, 2012.

17. HU A.B., REN X.X., YU S.W., DING N. Exploration for Creating Low-impact Development Stormwater Management Demonstration Area in Shenzhen. China Water \& Wastewater. 26 (20), 69, 2010.

18. DIETZ M.E., CLAUSEN J.C. Stormwater runoff and export changes with development in a traditional and low impact subdivision. J Environ Manage. 87 (4), 560, 2008.

19. ALFREDO K., MONTALTO F., GOLDSTEIN A. Observed and modeled performances of prototype green roof test plots subjected to simulated low and high-intensity precipitations in a laboratory experiment. Journal of Hydrologic Engineering. 15 (6), 444, 2010.

20. HOLMAN-DODDS J.K., BRSDLEY A.A., POTTER K.W. Evaluation of hydrologic benefts of infltration based urban storm water management. J Am Water Resour As. 39 (1), $205,2010$.

21. HOOD M.J., CLAUSEN J.C., WARNER G.S. Comparison of Stormwater Lag Times for Low Impact and Traditional Residential Development. J Am Water Resour As. 43 (4), 1036, 2010.

22. AHIABLAME L.M., ENGEL B.A., CHAUBEY I. Effectiveness of low impact development practices in two urbanized watersheds: Retrofitting with rain barrel/cistern and porous pavement. J Environ Manage. 119 (119C), 151, 2013.

23. LEE J.M., HYUN K.H., CHOI J.S., YOON Y.J., GERONIMO F.K.F. Flood reduction analysis on watershed of LID design demonstration district using SWMM5. Desalination \& Water Treatment. 38 (1-3), 255, 2012.

24. JAMES W., HUBER W., DICKINSON R., PITT R., ROESNER L., ALDRICH J. User's Guide to PCSWMM.
In: Computational Hydraulics International: Guelph, Ontario, Canada. 2003.

25. ZHANG P.L. Research on Simulation Model of Storm Runoff in Tianjin Urban District. In: Tianjin China: Tianjin University. 2007.

26. HUBER W.C., ROSSMAN L.A., DICKINSON R. EPA storm water management model SWMM 5. 0. In: Watershed Modeling: CRC Press; 339, USA, 2005.

27. ROSSMAN L. Storm Water Management Model (SWMM)-User's manual, Version 5.0.022. http://www. epa.gov/nrmrl/wswrd/wq/models/swmm. 2012.

28. SHAMSI U.M. Modeling Rain Garden LID Impacts on Sewer Overflows. Journal of Water Management Modeling. 2012.

29. SHRESTHA A., CHAOSAKUL T., PRIYANKARA DPMP., CHUYEN L.H., MYAT S.S., SYNE N.K., IRVINE K.N., KOOTTATEP T. BABEL M.S. Application of PCSWMM to Explore possible climate change impacts on surface flooding in a Peri-urban area of Pathum Thani, Thailand. Journal of Water Management Modeling. 2014.

30. IRVINE K.N, SOVANN C., SUTHIPONG S., KOK S., CHEA E. Application of PCSWMM to Assess Wastewater Treatment and Urban Flooding Scenarios in Phnom Penh, Cambodia: A Tool to Support Eco-City Planning. Journal of Water Management Modeling. 2015.

31. LIU X.P., LIU S.Q., LI S.P., JIAN H.U., YU YP. Computer Modeling Method for Drainage Networks in Central Zone of Zhenjiang City. China Water \& Wastewater. 23 (11), 42, 2007.

32. WANG R., Qin H., ZHAO Z. Control Studies of Peak Flow and Non-Point Source Pollution for Urbanized Area Based on SWMM. Acta Scientiarum Naturalium Universitatis Pekinensis. 51 (11), 141, 2015.

33. WANG W.W., ZHAO Z.J., Qin, H.P. Hydrological effect assessment of low impact development for urbanized area based on SWMM. Acta Scientiarum Naturalium Universitatis Pekinensis. 48 (2), 303, 2012

34. HE S., LIU J., ZHU J.Q. Runoff Control and Utilization Effect Assessment and Simulation of Low Impact Development Based on SWMM. Water Resources and Power. 31 (12), 42, 2013.

35. KANG T., LEE S. Development on an automatic calibration module of the SWMM for watershed runoff simulation and water quality simulation. Journal of Korea Water Resources Association. 47 (4), 343, 2014.

36. FU R., LUO L.H., LIU J., HE S. Application of Low Impact Development Module of SWMM in Drainage and Flooding Control System. Water Resources and Power. 32 (9), 71, 2014.

37. HOSSAIN S. Hydrological Modeling of Storm Water Drainage System due to Frequent and Intense Precipitation of Dhaka city using Storm Water Management Model (SWMM). In: 2015 AGU Fall Meeting: Agu.

38. LIU X. Parameter calibration method for urban rainfall runoff model based on runoff coefficient. Water \& Wastewater Engineering. 35 (11), 213, 2009.

39. HE F.L, HU C.H, WANG M., WANG Y.L, LI X.M. Application of SWMM in Planning and Construction of Urban Drainage System. Water Resources \& Power. 33 (6), 48, 2015.

40. CONSTRUCTION S., COMMITTEE T. The 2011 Version of the 'Code for Design of Outdoor Wastewater Engineering (GB 50014-2006)'. China Planning Press, 11, China. 2011.

41. ZHANG Z. Water and Wastewater Design Manual: Fifth 
volumes of urban drainage. China Architecture \& Building Press; 22, China. 2011.

42. WANG W.L., LI J.Q., GONG Y.W., ZHU M.J., ZHANG Q.K. LID Stormwater Control Effect Simulation Based on SWMM. China Water \& Wastewater. 28 (21), 42, 2012.

43. QIN H., LI Z., FU G. The effects of low impact development on urban flooding under different rainfall characteristics. J Environ Manage. 129 (18), 577, 2013.

44. ZAHMARTKESH Z., BURIAN S.J., KARAMOUZ M., TAVAKOL-DAVANI H., GOHARIAN E. Low-impact development practices to mitigate climate change effects on urban stormwater runoff: Case study of New York City. Journal of Irrigation \& Drainage Engineering. 141 (1), 04014043, 2014.

45. ZHANG S., GUO Y. SWMM Simulation of the Storm Water Volume Control Performance of Permeable Pavement Systems. Journal of Hydrologic Engineering. 20 (8), 1084, 2015.

46. LIAO Z.L, ZHANG G.Q, WU Z.H, HE Y., CHEN H. Combined sewer overflow control with LID based on SWMM: an example in Shanghai, China. Water Science \& Technology. 71 (8), 1136, 2015.

47. LUCAS W.C., SAMPLE D.J. Reducing combined sewer overflows by using outlet controls for Green Stormwater Infrastructure: Case study in Richmond, Virginia. Journal of Hydrology. 520, 473, 2015.

48. NIU S., HUANG J.H., CAO L., LI Y. Evaluation on the effect of Low Impact Development for Stormwater Management system on the hydrologic cycle. Building Energy Efficiency. 43 (2), 79, 2015.

49. ROSA D.J., CLAUSEN J.C., DIETZ M.E. Calibration and Verification of SWMM for Low Impact Development. JAWRA Journal of the American Water Resources Association. 51 (3), 746, 2015.
50. NIE T.F. Calculating techniques research on Guangzhou urban non-point source pollution load caused by stormwater runoff. In: Guangzhou China: South China University of Technology. 2012.

51. CHEN Y. Practical Study on Urban Rainfall Runoff LID-BMPs. In: Environmental Science and Engineering, Suzhou Jiangsu China: Suzhou University of Science and Technology. 2014.

52. WANG Z. Research of the Non-Point Source Pollution Load in Palm-spring Residential District Based on SWMM. In: Faculty of Urban Construction and Environment Engineering, Chongqing China: Chongqing University. 2007.

53. WU J.L, SUN F., DONG W., WANG H. SWMM simulation based analysis on rainfall runoff and water quality within urban inland river area. Water Resources \& Hydropower Engineering. 43 (8), 90, 2012.

54. LI M.Y., CHENG J.X., ZHOU T., ZHOU Z.N. Study on water quality control function and design method of residential green space distributed drainage system. Water and Wastewater Engineering. 40 (2), 81, 2014.

55. NIU Z.G., CUI Z.Z., CHEN Y.X. Situation and progress in the low-impact development of basic measures for performance. Journal of Safety \& Environment. 14 (6), 320, 2014.

56. CHEN Y. Study on optimization of rainstorm intensity formula in Fuzhou City. Water and Wastewater Engineering. 39 (10), 36, 2013.

57. ZHANG D.W., ZHAO D.Q., CHEN J.N., WANG H.Z., WANG H.C. Application of Chicago rainfall process line model in the simulation of drainage system. Water and Wastewater Engineering. 34 (S1), 354, 2008. 
